\title{
THE DOCTRINE OF THE SEPARATION OF POWERS IN SEVENTEENTH CENTURY CONTROVERSIES
}

\author{
Max Radin $\dagger$
}

It is no secret that John Marshall did not invent the doctrine that a court must refuse to apply an unconstitutional law, a doctrine which he somewhat unnecessarily dragged into the case of Marbury $v$. Madison. ${ }^{1}$ It is, however, still orthodox political history that Monsieur de Montesquieu was the father of the doctrine of the separation of powers in the form in which we understand it. ${ }^{2}$ While there is no necessary or logical connection between the separation of powers and judicial supremacy, the historical connection is close enough under such a system as that which the United States developed out of their English inheritance. One thing, however, is true. Whether these two doctrines were original with Montesquieu and Marshall or not, neither was coldly and austerely excogitated out of established premises by pure reason. For Marshall, the doctrine he announced was a weapon which might be effectively used against a hostile Anti-Federalist Congress. $^{3}$ In the case of Montesquieu, the separation of powers was the urbanely written protest of a gentleman and rationalist against a system of government that in theory subjected his life and estate to the whim of a capricious despot, although, to be sure, the despot had in fact no designs whatever on the life and estate of the president of the parlement of Bordeaux.

There is no doubt that Montesquieu's Spirit of the Lawes was eagerly and carefully read by Colonial publicists ${ }^{4}$ and particularly by many of the

$\dagger$ A. B., I899, College of City of New York; LL. B., I902, New York University; Ph. D., 1909, Columbia University; Professor of Law at the University of California; author of HaNDBOOK OF RoMan Law (1927); HandBook of ANglo-AMERICAN Legal History (1936) ; The LAW AND MR. Smith (I938); Glanvill on the Common Law (1933) 82 U. of PA. L. REv. 26, and of other articles in legal and philological periodicals.

I. I Cranch 137 (U. S. I803).

2. Certainly Krabbe in his Modern Idea of the State (Sabine's and Shepard's trans. I922) 25-27, seems to have no notion that the trias politica had any other source than Montesquieu. That Montesquieu claimed originality for his theories is generally assumed from the famous phrase prolem sine matre creatam, on which a whole literature is available. Cf. KLEMPERER, MONTESQUIEU (2 vols. I9I4-I915) [6 BeIträGe zUR NEUEREN LiteraturgeSCHICHTE 3-30]. The phrase, however, may not have this meaning at all. In general, for Montesquieu's sources we may refer to the almost exhaustive bibliography in LEVIN, THE PoLITical Doctrine of Montesquieu's "Esprit des LoIs": Its Classtcal Background (i936) 33I-359. While the bibliography in this book extends over eighteen pages and is doubtless the fullest that exists, it is not, after all, quite complete since it omits M. Albert Sorel's book, which is not only one of the most widely used studies of Montesquieu but has been several times translated into English. Again, the brief introduction by Holmes to a recent edition of the ESPRIT DES LoIS appears as a book in its own right.

3. It had the added merit that although the announcement of the Court's power seemed to reject a prayer for relief made by a Federalist office holder, the decision of the Court did not in fact deprive that Federalist office holder of his position.

4. There is a full reference to these in Knust, Montesquien und die Verfassingen der Vereinigten Staaten von Amerika (1922) 48 HIST. BIBL. A briefer account of Mon- 
men active in the Constitutional Convention. It is not, however, equally certain that they derived the doctrine of the separation of powers wholly from this reading. The extraordinary and fascinating book which Voltaire was too clever to understand, in the opinion of the author, and which Catherine II called her breviary, might have seemed to them a fine and convincing expression of an idea with which they were already familiar and which they might have liked to regard as English, as rational, and as divinely sanctioned.

The framers of the Constitution who had so much to say about the eminent Monsieur Montesquieu, were, in regard to practical matters, even more devoted to an element in their English inheritance which Montesquieu knew only imperfectly. That was so much of the common law as guaranteed or seemed to guarantee the rights of Englishmen. The majority of the members of the Convention were lawyers, ${ }^{5}$ and the law they studied most but not exclusively was the common law. They were conscious of its imperfections as a system of private law, but on the side of public law they regarded it as much superior to the civil law with which they constantly compared it. ${ }^{6}$ And what they valued most in it was its technical procedure.

Now, on one point there can be no controversy. There was no hint or trace of separation of powers in the common law's conception of governmental authority. The common law is first of all a special development of the medieval feudal law as it was administered in England by feudally thinking kings through agencies and commissions which grew chiefly out of the exigencies of their household management. This feudal concept was combined with the canonical concept whereby the king, as the head of the secular part of the Church, had the duty of protecting the Church and of maintaining justice. And, finally, the feudal and canonical ideas were fused with what may be called the imperial concept which worked powerfully for the establishment of the modern idea of nationality, and which

tesquieu's influence on the convention is found in Coolidge, Theoretical aNd Foreign INFLUENCES ON THE CoNSTitution OF THE UNITED STATES (Freiberg dissertation, 1892) 31-39. Cf. also, CatTelain, Etude sur l'INfluence de Montesouieu dans les Constitutions Américatnes (Besançon dissertation, 1927) ; Erlik, Les Idées de Montesquieu et la Constitution Anéricaine (I926) 43 REv. DE DRoIT PUB. I30. The general opinion that Montesquieu's influence was controlling is illustrated by Maine's statement, PoPULAR Governarent (1885) 218. Laboulaye, Montesquieu's Esprit Des LoIs (1875) intr. p. I6.

5. WARREN, HISTORY OF THE AMERICAN BAR (IIII) 2II-2I2, says that thirty-one of the fifty-five members were lawyers. That seems to be confirmed by the biographies of the members as far as these are mentioned in the Dictionary of American BIOGRaphy. It is quite true that membership in the colonial bar did not demand much special study and that the legal experience and training of some of these lawyers was extremely meager.

6. I Kent, Commentaries on American Law (I4th ed. I896) 547. The popular attitude is represented in the poem by David Humphreys, "The Happiness of America", published in 1786.

"The law for them and Albion's realms alone

"On sacred justice elevates her throne.

"Regards the poor, the fatherless protects,

"The widow shields, the proud oppressor checks." 
tended strongly to the concentration and integration of power, not to its separation into independent branches. This imperial theory was presented first as the result of the resplendent Roman system rediscovered in the twelfth century; but at the time that concerns us most, it was taken to be the inevitable conclusion of reason based upon natural conditions. We must note, however, that anti-imperialistic doctrine in the Middle Ages likewise cited the Roman law and likewise appealed to reason and nature. The great movement of critical rationalism which began with Descartes, Galileo and Grotius did not invent the importance of reason as the final criterion of a good law and as the only adequate justification of an existing law.

Separation of powers had no place in the common law. All power was in the king, conceived as a person or as a corporation. Legislation was carried on by the king in his Parliament-or as it was often expressed, with his "Estates"; ${ }^{7}$ administration by the king in his personal Council or Councils; judicature by the king in his courts, in all of which he was present and for every act of which only his writ gave validity. Again, the king had certain particular governmental rights by virtue of his prerogative and these rights might be exercised by him in his own person. Parliament -at any rate, the nucleus of Parliament, the House of Peers-was both the Supreme Court and the Common Council of the kingdom, while the judges of the other courts were of the king's counsel, and present at each Parliament if not members of it. The Star Chamber was consciously both Court and Council just as the Council of the North was. The Petition of Right is classed as a fundamental statute and is couched in the same form that is observed in a bill initiating an action in Chancery or a humble request for grace from the king. ${ }^{8}$ Most statutes in fact begin as "bills", that is, as petitions of the Commons. And Coke found no difficulty in Acts of Parliament-not merely Magna Charta-that were in the form of royal grants.?

In this inextricable interrelation no notion of separation of powers would normally develop. And it was the same in regard to the non-feudal elements in the kingly power, those derived from the canonical and imperial ideas. In both, the kingly office was the center and source of ordinances that had the force of laws, of administrative acts that kept the peace and warranted justice to all men, and of the judicial organization in which disputes could be finally determined by the king's judges.

To the Puritans, all these three conceptions of the kingly power were equally distasteful. The feudal or common law notion was in their eyes a

7. 4 Co. INST. *I, defining Parliament, says: "This court consisteth of the kings majesty sitting there as in his royall politick capacity, and of the three estates of the realm." TwYsDEN, THE GovernMENT OF ENGLAND (Kemble's ed. 1849) c. I2.

8. The Petition of Right of 1628 is regularly cited as a statute, 3 CHAs. I, c. I (I627), but it was a petition in the usual form and was assented to in the customary formula. "Soit droict fait", 5 HOLDSWORTH, A HISTORY OF THE ENGLISH LAW (3d ed. 1932) 451-454.

9. 2 Co. INST. proeme. 
foreign Norman perversion of ancient custom. The canonical theory made the king the chief minister of a superstitious and usurping institution, the hierarchic Church. The imperial theory was the announcement of a power specifically condemned in Holy Writ and allowed by God only for those hard hearts that had not been touched by Grace. To the Puritans, the proper source of power and law and justice could be found only by going back, first, to the divine law directly derived from the Scriptures, next to ancient custom reduced by its pristine form and purged from foreign elements, and finally to nature and reason, as expressed and formulated by soundly learned and grave doctors.

This did not mean that they were anti-monarchical. But it did mean that all human institutions of government were more or less casual and special. The government by king, lords and commons, through councils and ministers and courts, was ancient and long established and, therefore, well enough; but it could be changed and changed fundamentally.

The year I600 may be taken as a terminus. It is approximately the turning point of modern times; and in English history it is the threshold of the movement that saved England from the absolutist doctrine which was created by the Renaissance out of the Byzantine-Roman law, and which so admirably helped the formation of integrated nations out of the ruins of feudalism. England did not need the new monarchy to become a nation. It was already one, thanks chiefly to its relative isolation. The movement that resisted monarchy in England was political, religious and economic, but it was not social. It found its most eloquent and vigorous exponents in a group of small landowners-gentlemen for the most part-and in the upper reaches of the city-corporations where there was a definite mercantile aristocracy in control. Most of the leaders had university education. A certain number of them were lawyers; that is, barristers or serjeants. They not only constituted the upper strata of the middle class; but they were likewise an aristocracy among the sectarian opponents of the church and state, or rather of the Church-State community, since they were insistent that church and state were one.

Among these sectaries there were all degrees, from those who mildly questioned the divine institution of the episcopate to Antinomian zealots who preached the imminent end of the world and the dissolution of all the bonds and obligations of existing society. The Puritans who successfully carried out the revolt against the royal prerogative were for the most part "moderates", Presbyterians, or in extreme cases Independents; but they were roundly contemptuous of fanatic Brownists and Baptists and horrified by Anti-Trinitarian Socinians. None the less, it must not be forgotten that they demanded a much broader basis for the suffrage than existed at the 
time and that they quickly began to use phrases that looked forward to a general equality of political rights. ${ }^{10}$

Still, as we understand the terms, the Puritan revolt was not a "popular" movement at all, least of all a "proletarian" one. The principles most insisted on were freedom of trade by abolition of monopolies and restrictions, abolition of the feudal incidents of land tenure, reapportionment of representation in the Commons, and the suppression of Papists. ${ }^{11}$ As means to that end, regular Parliaments, not to be dissolved except by their consent, soon became a major part of the program; and it is a significant indication of the final form of their political thinking. But the special organization of the English government which had been worked out in the Middle Ages inevitably formed the background of the political thinking even of the Puritans. If the question of judicial supremacy had been formally raised with them, it could have been couched only on these terms: "May the king's judges disregard a statute made by the king in his parliament?" or perhaps, "May the king's judges distinguish between good statutes made by former kings in former parliaments and bad statutes, and reject the former?"

And even if that question had been so formulated in the minds of the Opposition, it would not have amounted to a declaration of judicial supremacy of one power over another for the simple reason that the powers of government were not in fact separate at all. If, in a given case, the king's court had denied redress to a litigant in spite of an act of parliament, the litigant had the obvious recourse of a direct appeal to the king. Whether this appeal would be determined by the king himself in his Court of Chancery presided over by the Keeper of his Great Seal or his Chancellor, or whether it would be determined by the king in his High Court of Parliament-still in some legal contemplation the upper House alone-was disputed. In any case, it was an appeal from the king in one court to the king in another and a higher court. ${ }^{12}$

It needs an effort of the will to recall that an Act of Parliament was not the act of an independent body in which the executive had only the

Io. The demand for the reform of the suffrage is a constant element in the successive petitions and formulas that were prepared in the Parliamentary interest.

II. The importance of this part of the Opposition's program is likely to be underrated. It was the one thing on which all groups-even the extreme Monarchists among the great landowners-were likely to be agreed. The fact that Charles I's queen was a Roman Catholic and that the English princes were first cousins of the young French king caused these gentlemen furiously to think. A great part of their most valued possessions consisted of confiscated abbey-lands, and only two generations had elapsed since a Catholic sovereign (Mary Tudor) had in part dispossessed the beneficiaries of the confiscation. If a Catholic king once more sat on the English throne, length of time would not help them. By Canon Law, as by Roman law (Nov. III, I; I3I, 6), no prescription ran against the lands of churches or of "pious foundations".

I2. That the Massachusetts Puritans thought of Parliament as one in a series of governmental bodies or courts may be seen in the statement from Lechrord, PlaiN Dealing (1642) 84: "They themselves say that in the generall courts and quarter courts, they have the power of Parliament, King's Bench, Common Pleas, Chancery, High Commission and Star Chamber and all other courts of England." 
minor role of attempted persuasion or dissuasion-as in the United States. A statute of the seventeenth century really was an act of the king himself which his Parliamentary counsellors had approved of or consented to. This was the picture that the Puritan leaders had of it; and while it was to their efforts more than to anything else that the fundamental transformation of political authority in England was ultimately due, this transformation was still in its incipient stage at the beginning of the Puritan movement in church and state.

As the Puritans grew more conscious of their political and economic needs, it was not the court system in which they felt they could find an adequate instrument. Not in the prerogative courts of Chancery or the Star Chamber, certainly not in the feudal courts of Wards and Liveries, and almost equally not in the two Benches nor in the Exchequer, was a Puritan likely to find persons who were anything else than royal officials -officials much concerned, to be sure, with their special and peculiar property, the common law, but with a common law in which the king's prerogative was as essential an element as the right of the subject to sue out a writ for a fee.

It is quite clear, on the other hand, that the instrument that seemed to fit their needs was the Commons' house of Parliament where, despite a strongly felt unfairness of distribution, men of their class were well represented. The Puritans never became a majority in Parliament until Colonel Pryde made his famous purge of dissentients. Until then, the Parliamentary party contained many shades of anti-prerogative opinion; but the majority of the members were on the side of the traditional government of England, by a King acting as Corporation Sole and incapable of acting in any other way. ${ }^{13}$ They were ready to cut through the intricacies of the feudal maze I have described; ${ }^{14}$ but the general distinction between the king at his Council Table, in his Parliament and in the exercise of his prerogative, they had no wish to obscure altogether. As far as judicial activity was concerned, the king gave judgment through his judges, and not in his own person; but the judges were of all kinds, from the Chancellor who was close to the king, to the members of the benches who held their patents for life or claimed they did, and in some cases held them by purchase.

Bitterly as some of the Parliamentary party fought what they thought of as an abuse of the prerogative, a great many of them were attached to the principle of the monarchy as such and did not regard it merely as a tolerable part of their ancestral and received system, as the Puritans did. These moderate monarchists, however, joined hands with the Puritans in seeking a considerable increase of power for their House of Commons. By

I3. For a full discussion of the corporate character of the Crown, see Maitland, The Crozen as Corporation (IgOI) I7 L. Q. Rev. I3I ; 3 Collected PAPERS (IgII) 244-270.

14. Supra p. 843. 
the almost universal practice of their own age and other ages before and after them, they rationalized a striking and fundamental change by proving in their own minds that what they sought had existed from time immemorial and had only recently by acts of tyrannous usurpation been pushed aside for the present situation.

As a symbol for this the magic name of Magna Carta served very well. It was usually spelled "Charta" at the time and so was rendered more symbolic by suggesting the familiar word "charter", while a charter in turn suggested fundamental and unassailable property rights. Magna Charta was all the readier to hand because it had already been used as a symbol by a group very different from those who now seized upon it. The "myth of Magna Charta", which modern historians have so sharply criticized, was revived rather than created by the Parliamentary opposition to Charles I. It had gathered a real aura about it as early as Edward I, whose confirmation of the Charters gave it statutory force for the first time. And not only was it reconfirmed by Edward III on several occasions, but in at least one of these confirmations it was given an extraordinary position. It came perilously near to becoming a written Constitution. All statutes, it is said in 42 Edward III ( 1368 ), to the contrary of the Great Charter and the Charter of the Forest, shall be holden for void. We shall have occasion to recur to this statute of Edward.15

The Magna Charta that had taken this form in 1368 was avowedly a list of the privileges of the great earls and other powerful feudataries, clerical and lay. The Aldermen of London whose liberties were also protected in that document were chiefly of Norman origin and dealt with these landowners as men of common interest, speech and blood, and almost of equal rank. There was no illusion then about Magna Charta's origin or character. It was, to be sure, a recital of established rights, not of newly created ones; but they were feudal rights and part of the Norman tradition. At most they went to Saint Edward the Confessor, the half-Norman king from whom William claimed his right to England.

I5. Coke did not think that this was merely a phrase. He recurs to it as a general principle in 3 INST. c. 48 in the very technical matter of waste for a year and a day of felon's lands, provided by Magna Carta, c. 22. "If 17 Ed. 2, cap. ultimo, be contrary thereunto, it is repealed as to the wast." Coke does not cite the statute of Edward III, but merely goes on the general assumption "that if any statute be made to the contrary of Magna Carta, it shall be holden for none." This is stated indeed in the proeme to 2 INST., that "if any statute be made contrary to the great charter, or the charter of the forest, that shall be holden for none; by which words all former statutes made against either of those charters are now repealed." All these statements are obviously referrable to statutes made before 42 EDw. III (1368). That statute, however, deals in set terms with the future as well as with the past. Coke uses the word "now" and, by his general reference to the charter, is very close to giving it a position that approximates a constitution.

We may note further that at the end of his commentary on the Charter, 2 INST. *77, he discusses the fact that the "statute" of Magna Charta is in form a grant from the king, "that neither he, nor his heires, shall seek out any thing, whereby the liberties in this charter contained shall be broken." Magna Carta. c. 38. Since every act of Parliament is an act of the king, the maintaining of this "constitution" is quite clearly brought within the royal oath. 
When in the reign of Elizabeth, the sanctified Charter began to appear again as a symbol, the great feudataries had long disappeared. There were, it is true, a new group of great landowning nobles; but they made no pretence to political power as a class since their economic control gave them something more valuable as individuals. Indeed, so far as they had political power in the Upper House, they were in favor of a strong monarchy although their enthusiasm for it was dwindling somewhat.

At any rate it was as a guaranty of property rights-not political liberty-that Edmund Anderson quoted Magna Charta in Cavendish's case, ${ }^{16}$ a case in which the right protected is one that is peculiarly distasteful to modern times, property in a judicial office; and it was as a protection of property that the clause, "No one shall be disseized", was principally valued.

What was, however, even more important was a consideration that was both political and economic. New mercantile interests found the existing mesh of feudal restrictions and "liberties" extremely irksome. New owners of lands thought of their property as investments, of which the profits ought to be calculable. They were not interested in a feudal status and complained bitterly of the feudal incidents which were essentially incalculable as investments and did not offer any compensatory power or influence. Both landowners and merchants saw in the king the source of increasing restrictions and the chief of all feudal landlords and exploiters of an obsolete system. Magna Charta was the eminent symbol of a force that had once beaten down the king and forced serious restrictions on the prerogative. Magna Charta became, therefore, the rallying cry alike of landowners and merchants whose growth the royal power hampered, as well as of Puritans whose reforming activities the royal head of the church frustrated. It was equally the refuge of royal officials who viewed their offices as patrimony, however willing they might be to use them in the royal interest.

The attitude of Coke on this question illustrates the ambiguous position of this latter group. Coke had begun as a zealous Attorney General with views of the prerogative that were rather "high", to use the then current terminology. In the dispute with Ellesmere and at the Hampton Court conferences, his rejection of the king's right to do justice in his own person was that of a zealous maintainer of the rights of the office he then heldhe was Chief Justice of the Common Bench-much as Anderson had insisted on judicial perquisites against a greater sovereign than James. But at first it was certainly not because Coke sought to derogate from the royal power in the interests of Parliament ${ }^{17}$ that he went from humble remon-

I6. I And. I52 (K. B. I587).

17. Coke would, of course, have preferred Parliaments to keep to matters of pure administration. Cf. 4 INST. * 4 I. "A good caveat to parliaments to leave all causes to be measured by the golden and streight metwand of the law, and not to the incertain and crooked cord of discretion." 
strance to vigorous opposition, until he became one of the authors of the new Magna Charta, the Petition of Right.

Magna Charta itself Coke identified with the ancient and immemorial common law, of which he held it to be not the first enactment but a late recapitulation. The fantastic fable of which this doctrine was a part, the fable that the English constitution had been established about rooo B. C. by Brut, the grandson of Aeneas, ${ }^{18}$ was not invented by Coke; but no one repeated it so often or so fervently as he did. The result was a strong declaration of the independence of the judiciary, but it was an independence from a direct interference by the king in his natural person. The king in his corporate or politic person was the source of the court's authority. No independence was desired from this sort of a king since by his nature he could not do anything judicial except by speaking through his judges-not through the flesh-and-blood person who happened to be king-and, therefore, he could not possibly do anything except declare the common law.

There is a difference, however, between judicial independence and judicial supremacy. Coke's judges are to be in their official capacity independent of the intervention of the king and his personal capacity. But that the king acting in his politic capacity through his judges is superior to the king acting in his politic capacity in his Parliament, or for that matter to the king acting within his regalia or prerogative or in the exercise of his administrative duties at his Council table, is not asserted in Bonham's case, ${ }^{19}$ which contains the much quoted statement that even an act of Parliament may be void. ${ }^{20}$

Coke was certainly not a Puritan. He joined the Parliamentary opposition to the king, partly out of personal and bitter rancor, but at least as much out of his profound and just conviction that the English Crown was limited and not absolute and that the author of the True Law of Free Monarchy meant to carry to a logical and theoretical extreme the de facto absolutism of the Tudors. His perverse history, which saw in Magna

I8. The story first appears in the early twelfth century in the famous history of the Britons by the Welsh bishop, Geoffrey of Monmouth, to whom we also owe the Arthurian story. It is not too much to say that Geoffrey's book was one of the two or three most influential books ever written in Great Britain.

19. 2 Brownl. 255 (C. P. I6ro). Cf. also Hobart's statement in Day v. Savadge, Hobart 85 (K. B. 16r4).

20. It is customary to refer to Coke's statement in Bonham's case as a vague generality. From what has been said, this is not so at all. The majority of the judges agreed with Coke that the statute in question, I4 \& I5 HEN. VIII, c. 5 (I522), was void. The report in 2 Brownl. 255 (C. P. I6IO) is quite authoritative even if it is not by Coke himself, and is explicit on the point.

Nor can the older cases and instances that Coke cites be brushed aside as generalities. They speak of specific statutes and speak with vigor. It will be found that they do not-so far as I have been able to check them-ever undertake to set aside, in whole or in part, any statute issued by the reigning monarch. But they do indicate an attitude toward statutes of previous monarchs that is very much like that of the fourteenth century with which Mr. Pluncknett has made us familiar in his Statutes aNd Their INTERPRETation the First HALF OF THE FourteEnth CENTURY (I922), and they furnish an additional indication of the slow development of statutory theory in England. 
Charta merely a restatement of ancient pre-Norman and pre-Saxon law and in the Petition of Right merely a second clarification of this venerable system, is of no real moment. While judge, he had been originally a supporter of the independence of a judiciary composed exclusively of royal appointees. Once he ceased to be a judge and became a member of the House of Commons, he developed into an equally zealous maintainer of the privileges of Parliament against the Crown and of the privileges of the House of Commons against the House of Lords.

Here he found eager supporters among the Puritans. From a practical point of view, the Puritans would have been extremely ill-advised to insist on any doctrine of judicial supremacy. The last place in the world in which they could expect to find a sympathetic hearing was in the court. Sir Edmund Anderson, who in Cavendish's case had not scrupled to affront the great Queen, had been hard and short with dissenters. Not only the Star Chamber but the two Benches detested religious busybodies and preaching saints. But in the House of Commons such persons were powerful, and all their efforts were directed toward giving Parliament an effective control of the administration in every respect. They knew that among the lords they had many supporters. There was no wide social gap between the mass of the peers and the gentlemen of the lower House. They formed an economically interdependent group and were inclined on the whole to act together unless the Presbyterians and Independents got out of hand in their zeal for Church reform. The Puritans, however, had little support among the judges.

When the rebellious Parliament offered terms to the king, these terms regularly involved the condition that all greater officials, including the Chancellor and Treasurer, and both the Chief Justices, must be appointed with the approval and consent of Parliament. The extremists wished to include all the judges. Sometimes it was even demanded that the judges hold their position only during the pleasure of Parliament. But we can be sure of one thing. If the Puritans with or without the accession of Coke girded themselves against the Crown, it was not in the interests of the judiciary, but in those of Parliament.

All this may be profitably examined in relation to a little pamphlet of considerable importance. One of the members of the Long Parliament was a Mr. Clement Walker, a barrister of the Middle Temple. ${ }^{21} \mathrm{He}$ had joined the Opposition, but soon developed an extreme hostility to the Independents, especially to Cromwell. After Naseby and the king's imprisonment, he was strongly for acceptance of the royal terms. Twice he was arrested, once

2I. For Clement Walker, see the account in the Dictionary of Nationac Biography. John Aubrey makes a brief reference to him in 2 AUBREY, Lrves (Clark's ed. I898) 273. In December I648, Walker had voted for the acceptability of the king's terms, and was duls "purged" out of Pariament by Colonel Pryde on December 6, 1648. 
for complicity in the riot of the apprentices against the House; and after the trial of the king, he was indicted for treason, committed to the Tower and died there in $165 \mathrm{I}$. Before that time, he had occasion to direct a bitter squib against the Independents, called the Mystery of the Two Juntos; and in 1647 he published the first part of his History of Independency, ${ }^{22}$ a violent diatribe against Cromwell, Ireton and the "Saints" in general, whom he prefers to call the Grandees. He omits no violent charge or malicious insinuation and on pages $166-173$ gives a list of the highly profitable preferments and estates the Grandees in control of the purged and obsequious Parliament had granted to themselves. It makes an impressive total.

The book was reprinted several times and was last published in the Restoration. It was, as might be expected, popular with the Royalists, in spite of Mr. Walker's earlier anti-royalist activities from which he does not altogether recede, since he admonishes his "most dread Sovereign" to accept the lessons of his misfortunes. But much could be forgiven a man who hated Cromwell so bitterly.

Walker wrote under the pseudonym of Theodorus Verax, "Truthful Theodore". His attack drew a violent reply from the poet, George Wither. ${ }^{23}$ Like so many of his contemporaries, Truthful Theodore cried loudest when the shoe pinched hardest. When the House of Commons sought to examine him for the riot which he was accused of encouraging, he was asked to put on a gray suit because one of the witnesses remembered a gray suit but could not swear that he recalled Walker when he appeared in another suit. ${ }^{24}$ Walker protested that he was being forced to testify against himself contrary to Magna Charta and "due process of law" as contained in the statute of Edward III, and to everything else he could think of that was sacred and established.

But the outcries of Truthful Theodore in a matter that went so close to him are of less interest to us than several statements that he makes in another connection as part of his theory of government. These passages are of the highest interest. $\mathrm{He}$ is inveighing against the usurpation by the House of Commons, out of which he had been purged by Colonel Pryde, of the entire authority of the State.

“. . . yet it is most certaine, that when the 3 Estates in Parliament have passed any Act, their power determines as to that Act, and then

22. The copy of Walker's book in the possession of Professor O. K. McMurray is the same as that in the Harvard Library. Its complete title page runs: ReLATIONS AND OBSERVAtions, Historicali and Politick upon the Parliament begun Anno Dom. I640. Divided into II Bookes: I. The Mystery of the two Iunto's Presbyterian and Independent. 2. The History of Independency, etc. TOGETHER WITH An APPENDIX, touching the proceedings of the Independent faction in Scorland. Printed in the Yeare, 1648 . It is bound with a little treatise on the Divine Right of Church Government, which I have not identified. It is certainly not the work of Walker.

23. Respublica Anglicana or the Historte of the Pardianent (1650); see Spenser Soc. Pub. No. 36 (I883).

24. Cf. 4 WigMORE, EvIDENCE (2d ed. I923) §2265. 
the Authority of the Judges begins, which is Judicative: whose office is (upon cases brought before them) to determine whether that Act be binding or no; (for Acts of Parliament against common right, Repugnant, or Impossible, are Void, Cook. 8. f. Ir8. Dr. and Student, I. I c. 6) and to expound the meaning and signification of the words of such Act." 25

"Cook $8 \mathrm{f}$. II 8 " is, of course, the famous passage in Bonham's case which Mr. Pluncknett has made the subject of an admirably lucid and exhaustive study. ${ }^{26}$ It may none the less be well to restate once more for purposes of comparison just what Coke did say.

"And it appears in our Books, that in many Cases, the Common Law will controll Acts of Parliament, and sometimes adjudge them to be utterly void: For when an Act of Parliament is against Common Right and Reason, or repugnant, or impossible to be performed, the Common Law will controll it, and adjudge such Act to be void. . .." 27

There are other passages in Coke's writings that may be specially cited. In Calvin's case, so much discussed in other connections, he says : ${ }^{28}$

"By the Statute of 25 Ed. 3. cap. 22. a man attainted in a Praemunire, is by express Words out of the King's Protection generally; and yet this extendeth only to legal Protection, as it appeared by Littleton, fol. 43. for the Parliament could not take away that Protection which the Law of Nature giveth unto him; and therefore notwithstanding that Statute, the King may protect and pardon him. . . . A Man outlawed is out of the Benefit of the Municipal Law; . . . and yet he is not out either of his natural Ligeance, or of the King's natural Protection; for neither of them is ty'd to Municipal Laws, but is due by the Law of Nature, which (as hath been said) was long before any Judicial or Municipal Laws."

It is important to keep in mind that Coke did not state that some acts of Parliament are void in a general and vague phrase, as Blackstone ${ }^{29}$ does, but he quite specifically declares that definite and named statutes are void. The Statute I4 and I5 Henry VIII, 8, cap. 5, which created the College of Physicians, was void because it made the censors of the College judges in

25. WALKER, op. cit. supra note 22, at II4.

26. Pluncknett, Bonham's Case and Judicial Review (1926) 40 HARv. L. Rev. 30.

27. 8 Co. II4, II8 (C. P. I610). Attention must, however, be called to the fact that the phrase in Bonham's case is "common right", not "common law". It has been several times cited as though the latter were the reading. As an example we may instance the statement in the first volume of $\mathrm{Mr}$. William Haller's facsimile reprint with commentary of several seventeenth century tracts (I934) at p. I8I. Coke, however little he liked statutes, could hardly have doubted that statutes, when within the authority of Parliament, did change the common law, since his whole theory of statutory interpretation is based on the assumption that they did. Cf. Heydon's Case, 3 Co. 7 (C. P. I585).

28. 7 Co. I, I4 (Ex. 1608).

29. I BL. CoMrs. *9I (with Hammond's note). 
their own case, which was against natural law. The Statute 25 Edward 3, cap. 22 was void if it provided-as it explicitly did-that the king could not pardon certain types of outlawry. The bond of allegiance which involved the duty and power of protection were created by natural law and could not be avoided by act of Parliament. ${ }^{30}$

When we turn to the second citation on which Truthful Theodore bases his assertion, the passage in Doctor and Student, we find the same situation. Coke does not cite it, although he ordinarily makes copious use of St. Germain's book, nor is it referred to in Mr. Pluncknett's discussion. It is worth citing in full:

"The second ground of the law of England is the lare of God: . . . and also if any general custom were directly against the law of God, or if any statute were made directly against it: as if it were ordained that no alms should be given for no necessity, the custom and statute were void. Nevertheless the statute made in the thirty-fourth year of king Edward III, whereby it is ordained, that no man, under pain of imprisonment, shall give any alms to any valiant beggars that may well labour, that they may so be compelled to labour for their living, is a good statute, for it observeth the intent of the law of God." 31

Again there is nothing here that is vague or general. It is a specific statute that is stated to be void, unless it is capable of a definite interpretation. Nor can it be said that St. Germain does not contemplate that a court will so declare it, or that he merely expresses his conviction that Parliament should pass no such statute. The words he uses are precisely the same as those he employs when he says that a custom that is unreasonable or against religion is void, and he obviously assumes that in a given case a court will refuse to enforce such a custom. There is no reason to think that he has anything else in mind when he uses identical language about a statute.

If, then, we attempted to draw up a constitutional bill of rights ${ }^{32}$ which, according to Mr. Clement Walker, a statute must not violate, it would

30. If we speak of generalizations, the omnipotence of parliament has never so fully been stated as by Coke himself, 3 INST. *36. "Of the power and jurisdiction of the parliament for making of laws in proceeding by bill, it is so transcendent and absolute, as it cannot be confined either for causes or persons within any bounds. Of this court it is truly said huic ego nec metas rerum nec tempora pono." Coke is quoting the Virgilian line, AEN. I, 278, in which Jupiter promises unlimited empire to Rome.

3i. I St. Germain, Doctor and Student, c. 6.

32. The history of written constitutions has yet to be fully investigated. Besides the obvious forerunners of the American Constitution in such documents as the Instrument of Government (I653) and the Agreement of the People (I649), there are a number of charters and charter-like documents of the period that are clearly in the line of succession. Mr. Fulmer Moon, A Broadside Advertising Eleutlera and the Bahama Islands in 32 Cor. Soc. Mass. Trans. (1934) 78-86, has called attention to a charter of the Bahama Company which is nothing more nor less than a constitution of an aristocratically governed republic, with a measure of democracy. Similar documents await study. The practice of treating the political growth of the thirteen colonies from New Hampshire to Georgia as though they were isolated 
not contain merely vague generalities about the law of nature and reason or the law of God; but would certainly have at least three specific sections, one of which is of wide generality:

I. No statute must permit a person to be judge in his own case.

2. No statute must exclude an outlawed man from royal pardon.

3. No statute must prevent the performance of the duty of giving alms or of other positive precepts of the New Testament.

If we add Mr. Walker's objection, we may say that an act of Parliament which makes treason of a commoner triable before the House of Peers is also void and contrary to the proper "constitutional" organization of Englishmen. This statement we must regard as sufficiently extraordinary. If Mr. Walker could have supported it, he would have gone far in bringing the English legislature into the position of the American Congress, a body which may not validly pass a statute that goes beyond the powers which reasonably belong to it and above all a body which must not usurp the functions of the other divisions of the government.

What are these divisions? As to that Mr. Walker is quite specific:

"The KING is the only supreme Governour of this Realme of England, to regulate and protect the people by commanding the Laws to be observed and executed; and to this end $\mathrm{He}$ (and $\mathrm{He}$ alone) beareth not the Sword in vaine; yet the KING by himselfe can neither make, repeal, or alter any one law, without the concurrence of both Houses of Parliament, the Legislative power residing in all three, and not in any one. . . . Nor can the King by Himselfe, or joyntly with the Lords and Commons judge what the Law is, this is the office of the sworne Judges of the two Benches and Exchequer, who are the known Expositors, and Dispensers of Law and Justice in all Causes brought before them; yea, they do declare by what Law the King Governs, thereby keeping the KING from Governing Arbitrarily and enslaving the people. . . . Now for any one man, or any Assembly, Court, or Corporation of men (be it the two Houses of Parliament) to usurpe these three powers: I. The Governing power. 2. The Legislative power. 3. And the Judicative power, into themselves, is to make themselves the highest Tyrants, and the people the basest slaves in the world; for to govern supremely by a Law made, and interpreted by themselves according to their own pleasure, what can be more boundlesse and arbitrary?" 33

On the following page he states specifically what the substance of these three powers is:

developments and of ignoring the West Indies, Canada and Ireland was a capital error that modern historians are rapidly correcting. For the earlier quasi-constitutional documents we may compare the excellent and recent publication of Professors Carl Stephenson and Frederick G. Marcham of Cornell University, Sources of English Constrtutional History (I937) 503-533, especially $5 \mathrm{II}$ and 525 .

33. WALKER, op. cit. supra note 22 , at I50-I5I. 
"I. For the Governing power. I. They coyne, enhaunce, and abate money. 2. They make War and Peace, and continue an extraordinary Militia of an Army upon us. 3. They declare who are Enemies to the Realm. 4. They maintaine forraine negotiations. 5. They regulate matter of Trade, and exercise other Regalities: whereas all Iura Regalia belong only to the King as Supreme Governour.

" 2 . For the Legislative power. They exclude the King from His Negative voice, and the two Houses obtrude their Ordinances (things so new, that they are not pleadable in any Court of Iustice) as Laws upon the people; laying on Excise, Assessments, and Taxes upon the people: They Vote and declare new Treasons, not known by the statute 25. Edw. 3 nor by any other known Law; yea even to make or receive any addresse to, or from the King; and they account it a Breach of Privilege, if men do not believe it to be Treason, being once declared. They out men of their free-holds, and imprison their Persons, contrary to Magna Charta, by Ordinances of Sequestration, \&c.

"3. For the Iudicative power. They erect Infinite many of new Iudicatories under them, as their Committees of Complaints, of secret Examinations, of Indempnities; their Country Committees, where businesses are examined, heard, and determined without, nay against Magna Charta, and the known Lawes: nay even in capitall crimes they wave the Courts of Law, and all Legall proceedings by Outlawry, Indictment, or Tryall by Peers, and Bill of Attainder; (which is the only way of Tryall in Parliament: For the Parliament cannot judicially determine any thing, but by Act of Parliament). . . ."34

It is difficult to read this without noting the fact that the doctrine of the three powers, and their complete and necessary separation are as fully stated as they are in Montesquieu. If we ask ourselves where Walker got it, it would be hard to identify the source. Certainly not from Coke who nowhere says anything like it, not even in this Third Institute where we should expect to find it, if anywhere, and where on the contrary, Coke rates the High Court of Parliament as of the same type of those exercising the "iudicative" powers of Walker's division.

It is important to call attention to the fact that the distinction is made, and the unconstitutional action of the Parliament is especially attacked, in the course of an argument that begins with a vigorous defense of the royal power and continues in that strain.

So far from being a generally accepted or usual division, it is somewhat opposed to the contentions of either party. The extreme Monarchists rejected it since in their view the king had all power and the function of Parliament was at best consultative. Sir Robert Filmer finds two powers in government, legislative and executive, neither of which by nature of English law could be exercised by Parliament. 
The Parliamentary party were naturally much disinclined to place themselves on a mere equality with the other parts of the government during the bitterness of the conflict. That all power rested with Parliament, men were not ready to say, except the Levellers and other extremists. However, since they arrogated to themselves the right of abolishing the other parts of the government or reorganizing them-as Walker quite correctly asserts they did-they can scarcely have admitted a mere equality. And after I689 when a moderate and bourgeois parliament took complete control of England, they had no need of asserting a dominance that was no longer questioned de facto.

As far as later discussion goes, we know that Locke recognized merely the legislative and executive powers to which he added the federative. It is generally acknowledged as an achievement of Montesquieu that he set the judicial function as coordinate with the others and independent of them; and that, as has been seen, is unequivocally the position of Walker, our Truthful Theodore.

Walker's pamphlet was republished during the Restoration and had a limited vogue. It is not impossible that Montesquieu had read it. ${ }^{35}$ But it was distinctly not a book that Puritans would approve of-at any rate Puritans who cherished any devotion to the memory of Cromwell, the bitter enemy of Walker. We may recall, however, that there were many devoted monarchists even among the people of New England, and that in other colonies Cromwell was anything but a saint. Those who successfully established the principles of the Glorious Revolution were monarchists, even if they were not absolutists. They did take over some of the heroes of the struggle against Charles, Coke notably, Pym and Hampden, Sir John Eliot and of later names such persons as Algernon Sidney, despite his republican tendencies.

John Eliot had the rank of a Parliamentary martyr. He was tried and convicted in the King's Bench for acts done in Parliament and his plea of Parliamentary privilege expressly denied. He was fined the exorbitant sum of $£ 2000$ and committed to the Tower, where Charles, in a fit of obstinate

35. If we may credit Mr. George Saintsbury in his article on Montesquieu in 18 ENCYC. BRIT. (IIth ed. I9I0) 778, "there is known to exist at La Brède a great mass of MS materials for the Esprit des Lois-diaries, letters, notebooks and so forth." Only a small part of this has ever been permitted to be published by the modern representatives of the family, towit, two minor essays published in I89I and I894. Since the literature of the Puritan revolution circulated widely in France, it is not at all unlikely that Walker's book-sufficiently important to be twice re-edited in England-may have got to Bordeaux or La Brède. This has all the more plausibility when we recall that the pamphlets of even the most extreme "leftists" of the Puritan revolt, the Levellers, were cited in a petition addressed by the Bordeaux parliament to the Crown during the Fronde. There is no mention of Walker in DEDIEU, Montesquieu et la Tradition Politioue Anglaise en France. Les Sources Anglaises DE L'ESPRIT DES LOIS (1909). Nor is there any reference to him in such presentation as we have so far had of the books at Montesquieu's disposal. However, no complete publication of his notes has so far been attempted. Cf. Transactions of the Academy of Agen for 1834 (not seen) where the Montesquieu papers are discussed. 
vindictiveness, allowed him to die. Some of his writings were known to the Colonists. His chief book, however, De Jure Majestatis, was not published till modern times. ${ }^{36}$ Whether it circulated in manuscript, we cannot tell. Under all circumstances, the ideas he had must have been communicated and may well have been the common property of many of his group. Eliot was a man of wide learning. His margins are filled with annotations, containing references to classical and medieval writers. Like Waiker, he has a well-defined theory of three governmental powers, but in his case there is no uncertainty about its derivation. Eliot cites Aristotle. ${ }^{37}$

Precursors of Montesquieu have often been found. There is the constantly repeated statement of Maine that Marsilius (Marsiglio) of Padua had set forth a complete doctrine of the separation of powers in his Defensor Pacis, written about $1324{ }^{38} \mathrm{He}$ gives no detailed reference and a careful examination of the book does not show any passage that can be clearly so interpreted. ${ }^{39}$

The same can be said of the passages in Buchanan's De Jure Regni apud Scotos which have also been taken to involve a notion of the separation. Buchanan, to be sure, will not permit the king to interpret the laws, but he does not deprive the king of his share in making them. Nor is there anything to indicate that he meant to deny the subject the right of recourse to the king for denial of justice. Such a right of appeal, however, involves a certain amount of judicial function.

As far as Hooker is concerned, the separation involved is expressed in fairly general terms and may be little more than a modified recollection of Aristotle.

36. It was published in I 882 by Alexander B. Grossart in two volumes. The first volume contains the treatise on the royal power which well repays reading for all purposes. The second volume contains Eliot's letter-book.

37. I De Jure Majestatis (Grossart's ed. I882) 95. The passage is Aristotle, Politics Book IV, c. I4. It appears in this order in most of the manuscripts. Some modern editions have rearranged the books and cite the passage as VI, c. I4. The more familiar method is to cite it as $1297 \mathrm{~b}, 4 \mathrm{I}$.

38. Popular Government (I885) 219, n. 9.

39. He gives no other reference and I can find no trace of the doctrine in that book, in the standard edition of C. W. Previté-Orton of Cambridge (I928). On the contrary, in Dict. I, c. II, I40-48, there is a double division in which the pars iudicans is regarded as an aspect of the pars principans. Further, as we should expect in a devoted imperialist, Marsilius in his DEFENSTo MINOR (Brampton's ed. I922) c. I3, 4I-44, declares that the legislative power has also been conferred on the pars principans. Similarly in the DEFENSOR PACrs, Dict. I, c. 17, he insists on the unitas of the governmental power.

Marsilius often cites the PoLITICs which he knew well, but not the section in which this division is made.

The passages from Marsilius cited by Leonhard, Ursprung des Primats der GesetzGEBUNG (Erlangen dissertation, 1926) 5-9, are equally general and are far from bearing out Maine's assertion. The same may be said of the brief references to Marsilius in Klimovsky, Die englische Gewaltenteilung bis zu Montesquieu (Germany, 1927) ARCHIV FüR RECHTSUND WIRTSCHAFTSPHILOSOPHIE, Beiheft, which do not deal with the separation of powers so much as with the classification of governments. I have not been able to see JANNSEN, MoN-

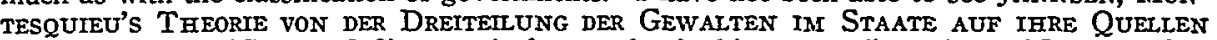
ZURÜCKGEFÜHRT (Gotha, I878), a study frequently cited in recent discussions of Montesquieu. 
What is likely to be forgotten is that the doctrine of the separation of powers is not the same thing as that of the independence of the judiciary. The latter idea arose apparently-at any rate, to some extent-out of the property interest that judges had in their office. It did mean, of course, that judges might develop an independence in regard to the Crown; and if they were high minded men, it meant that they might refuse to wrest justice at the demand of the Crown to the prejudice of the litigants. A completely independent group of judges whom the king might not dismiss or punish arbitrarily did not exclude a very considerable group of judges whom the king might dismiss; nor did it prevent the king, if he chose, from exercising judicature in his own person. The separation of powers demands that this may not be done by anybody but duly qualified judges, to any degree whatever. Montesquieu seemed clearly to think this the ideal system, and Walker seems to say the same thing.

Of course, a sharp insistence first on the complete independence of the judiciary and next on the permanence and inviolability of their jurisdiction -if this is wide enough-will almost completely separate the judicial functions from the legislative and executive. Coke would not only deny the power of the king in his own person to judge a case but would make the king's order no justification in a return of a writ of habeas corpus. Since, besides, he wished to limit all prerogative courts to the sharpest and narrowest bounds, it would amount to a separation of functions in practice that is as complete as can be desired. Yet in Coke no assertion of anything like a doctrine of separation can be found.

That Aristotle's division is very close to that we have usually accepted as that of the Spirit of the Laws would hardly have needed proof, if it had not been astoundingly denied by modern writers. In Zeller's great work on ancient philosophy, it is briefly declared that Aristotle's division does not correspond at all to that of modern theory. ${ }^{40}$ This need not surprise us in a quite unpolitical German scholar, but Mr. W. H. Newman in his admirable edition of the Politics, ought surely to have known better. ${ }^{41} \mathrm{Mr}$. Newman amplifies Zeller's objections by pointing out that Aristotle's legislative function includes the power of making war, peace and alliances, of decreeing death, exile and confiscation, which are part of the executive function. Even if we admit that they might be so regarded, we should only have a very slight overlapping, not as great as that which exists in any of the constitutions that have officially adopted the separation of powers as the basis of their system.

Aristotle as the source of Montesquieu's doctrine would adequately account for its appearance independently in Walker, but it might also ac-

40. 2 Geschichte DER GRIEChischen Philosophie, ii, 949, n. 5, translated as "Aristotle and the Earlier Peripatetics", ii, 283.

41. 4 Newhan, The Politics of Aristotle (Ig02) 429. 
count for a much greater familiarity with it than historians of politics usually allow. ${ }^{42}$ It must surely be given some place in the chain of causes that created our doctrine. Mr. Thayer, in his still unsuperseded Cases on Constitutional Law, cites the passage from Aristotle in its proper place, next to Locke and Montesquieu. ${ }^{43}$ Similarly Barthélemy St. Hilaire in his translation of Aristotle's Politics cites Montesquieu with general approval but says in regard to the doctrine of separation "il a omis de rappeler qu' elle était l'oeuvre d'Aristote." 44

The difference between Aristotle's doctrine and that to which Montesquieu's name is attached, lies not in the question of whether this or that power is properly executive or legislative but in the fact that Aristotle does not assert, and can hardly have meant, that each of these three functions must be kept quite separate from each other. The division of the three was a matter of pure analysis. ${ }^{45}$ When Sir Robert Filmer discusses Aristotle's Politics, he finds no difficulty in admitting any division desired of governmental power, provided final and supreme authority is left with the king.

The modern applications of the doctrine of the separation of powers, especially in France, have derived from it the rule that legislative acts may not be questioned by the judiciary since in logic the three powers are coordinate and wholly distinct. Walker, as we have seen, draws the conclusion-quite proper for an English lawyer-that, since the interpretation of statutes is left to the court and since interpretation of a statute begins with the question of power to make it, the court cannot help inquiring into this power.

Indeed he raises a question in another connection that is of the same sort but has fared quite differently in the history of English judicial theory. The Parliament whom he so furiously attacks, had declared that one of their own statutes - here called ordinances-was void because obtained under duress. Walker vehemently denies that any government can avoid their own acts by force.

"That the Supream power of no Nation can avoid their owne acts by pretended force: this would make the Common People, the Iurors, and Iudges to question all Acts done in Parliament, since one

42. CoOLIDGE, op. cit. supra note 4 , at $32, \mathrm{n}$. $\mathrm{I}$, asserts that "Aristotle is certainly not clear on the subject." It is hard to justify this criticism. Aristotle's statement is perfectly definite.

43. I Thayer, Cases on Constitutional Law (1895) I-2.

44. First published in I837. The third edition is of 1874 . The criticism of Montesquieu is on pp. lxxxv-cxil, and the discussion of the three powers on pp. xciv-xcy.

45. The comparison between the influence of Aristotle and that of Montesquieu made by Bluntschli in Montesquieu's favor, I Aligemeines STAATsReCht 376; and also by 3 MoHL, Geschichte uND Literatur der STAatswissenschaften (I858) 386 , is quite general and does not deal with the separation of powers specifically. An instructive parallel can be drawn between the doctrine of checks and balances set forth by Polybius and that of Montesquieu. Polybius, like Montesquieu, attempted to analyze the Roman state, a strikingly successful government which he did not quite understand; and managed to make his analysis the accepted doctrine of the Romans themselves. 
man can, and may judge of Force as well as another; this were to bring the Records of the House into dispute: Magna Charta was never gotten nor confirmed but by Force: Force was three-fold, upon one or both Houses; or upon the King, in giving his Royall assent; neither could plead it: the Parliament is presumed to consist of such men as dare lay downe their lives for their Country." 46

That this statement is not easily reconcilable with his strong assertion of the court's power to pass on the invalidity of Acts is clear enough. But on this point, his doctrine is in line with later English law.

What has seemed Montesquieu's special contribution is that these three powers must not be united in a single agency and that when they are so united, the result is tyranny. And this one point is specifically and definitely made by Clement Walker-Truthful Theodore as he styles himself, St. Clement, as he is derisively styled by George Wither-when he calls the rule by the Rump Parliament a tyranny, just as Montesquieu made the same point, in order to prove that the Continental systems were decently garbed tyrannies.

Walker thought of judicial review of statutes as a weapon in the hands of the king. Coke, in spite of his later Parliamentarism, advanced his statement of the doctrine on behalf of a contention favored by the Crown; and both in his Reports and his Institutes is anything but a lover of Acts of Parliament, which he repeatedly treats as unwarranted interference with the orderly and adequate development of the common law. When, however, we find the Puritan doctors announcing the doctrine, we shall see a definite and different point made.

John Lilburne's statement of the limitation of the power of Parliament is very generally phrased. The same can be said of Overton's. "The Levellers" as a group, were of a similar opinion; and, as we have seen, Sir John Eliot qualifiedly supports it. Cromwell held the same view. Nor was this merely an assertion of pamphleteers. In at least two cases, Commonwealth judges give emphatic expression to a doctrine which had, in these other statements, a vague and rhetorical tinge.

"By the law of England, that you desire to have the meaning of it, is but just; but you must know that the law of England is the law of God; and if there by any thing in the law of England, but what was by admirable constitution and reason, we would not meddle with it." 47

"Lord Keble. You say well: the law of God is the law of England; and you have heard no law else but what is consonant to the law of reason, which is the best law of God; and here is none else urged against you." 48

46. WALKER, op. cit. supra note 22, at 49.

47. 4 How. St. Tr. (I809) r 289.

48. Id. at 1307 . 
"The next thing is this; because you often fall upon distinctions of the law, and that you are ignorant of the law; the more to blame you, that profess the learning of the law of God; for there is no law in England, but is as really and truly the law of God as any Scripturephrase that is by consequence from the very texts of Scripture: For there are very many consequences reasoned out of the texts of Scripture; so is the law of England the very consequence of the very decalogue itself: And whatsoever is not consonant to Scripture in the law of England, is not the law of England, the very books and learning of the law: Whatsoever is not consonant to the law of God in Scripture, or to right reason, which is maintained by Scripture; whatsoever is in England, be it acts of parliament, customs, or any judicial acts of the Court, it is not the law of England, but the error of the party, which did pronounce it; and you or any man else at bar may so plead it. And therefore to profess you are knowing in the laws of God, and yet to be ignorant of the laws of England, when yet the laws of England be so purely the laws of God, as no law in the world more practical at this day-for you to be ignorant of them is not to your commendation, nor to any of your profession." 49

Mr. Justice Keble accordingly is at one with the Levellers and Irreconcilables whom he is condemning. He is for the Parliament against the king and for the Commons against the Lords. But he may be taken quite seriously in his belief that Parliamentary power, even if Parliament were exclusively manned by the godly and the saints, was definitely limited by the law of God as stated in the Bible. So far from Parliament being omnipotent, he would clearly have regarded a law that brought back papal government of the English church as not merely a bad law, but wholly void, not to speak of laws that clearly and unmistakably violated a Biblical command.

This is the tradition of St. Germain, and part of the consistent Church doctrine that all secular laws were void that were contrary to the law of God, whether revealed in Scripture or in natural reason. And, curiously enough, this eminently Catholic ecclesiastical principle remained the definite restriction which ardent Parliamentarians, who were bitterly anti-ecclasiastical, placed upon the governmental agency in which alone they had any confidence. Like the theory of St. Germain, of Coke and of Walker, it was not a glittering generality, nor a mere pious gesture. They had definitely in mind statutes that might easily be passed, or which had in fact been passed, which they would regard as null and void because they overstepped the limits of legislative power.

But there was a distinct difference between the Puritan theory of how far Parliament could go and the one which Coke advocated-and by no means solely in Bonham's case-and which Walker derives from the distribution of the functions of government into three independent parts. The

49. 5 id. at $x 7 \mathrm{I}$. 
Puritans were clear that a Parliament in which an elected House of Commons was dominant could make any change that was not forbidden by divine law. The men whose attitude was expressed by Coke-the newly created middle class of non-feudal landowners and merchants-had a larger set of limitations. They had worked out of Magna Charta and a few additional statutes, something so like a written constitution that it is hard to distinguish a Parliament limited by those statutes from a Congress of enumerated powers under the Constitution of the United States.

Did the colonial publicists know the work of Walker? There is no doubt that some at least of them must have been familiar with it. There was a copy in the Harvard Library which survived the burning of the library in $1764 .{ }^{50}$ This does not quite prove that Walker's statements were specifically in the mind of the colonial disputants. But the presence of the book indicates that some persons knew it and may have used it.

Parliament, we may remember, had in 1368 declared that statutes in violation of Magna Charta were to "holden for void". This is specifically referred to by Coke, apparently with approbation. Evidently logic makes it impossible for one session of Parliament to limit its successors and Coke himself points this out. ${ }^{51}$ It is a commonplace of ancient as well as modern political thought. Seneca calls attention to the fact that it would be necessary merely to repeal the prohibition of repeal in order to get rid of a nonrepealable statute. None the less the presence of such words as "forever" in statutes indicates that neither logic nor experience has succeeded in preventing legislative attempts to bind the future; and Coke himself, who so triumphantly argues this point, was largely instrumental in securing the passage of the Act that abolished the Courts of Star Chamber and High Commission tribunals he loathed with a special Cokian intensity, and did so by a statute which assumed to settle a thing beyond the power of future Parliaments to unsettle: "And be it further enacted that from and after the said first day of August, no new Court shall be erected or ordained or appointed within this realm of England or dominion of Wales, which shall or may have like power, jurisdiction or authority as the said High Commission Court now hath or pretendeth to have." 52

The point is that notwithstanding logic, legislatures during the seventeenth century did suppose that there were differences between statutes and statutes, and that some could be recognized as of constitutional effect.

50. It was the gift of Thomas Hollis, who donated a large number of books to Harvard during that period. It is mentioned in the Catalogue of the Harvard Library published in 1790. I owe this information, as well as a detailed description of the copy, to the kindness of Mr. T. Franklin Currier, Assistant Librarian of the Harvard College Library.

5I. We may note especially the discussion in 4 Co. INST. *42 et seq. "Acts against the Power of the Parliament subsequent bind not." Cf. also TwYSDEN, op. cit. supra note 7 , c. 16.

52. I6 Chas. I, c. Io (I640). 
It may be well to note another fact which gives Coke's doctrine a consistency not always found in his pronouncements and not so eminently present in the modern form of the doctrine of limited power in legislatures. There were things Parliament could not do-which meant, in reality as well as in theory, in Coke's day, that there were things the king could not enact in his Parliament. That same limitation rested upon the king at his Council Table. Indeed Coke's whole parliamentary activity was a protracted opposition to acts the king sought to do by proclamation, by order in council, or by mandate under his great seal. Tonnage and poundage, ship-money, dispensation of statutes, forced benevolences, these were all royal acts that violated Magna Charta and were, therefore, unconstitutional. It was in connection with the attempt of James II to do some of them that Blackstone-apparently for the first time-uses the word "unconstitutional." 53

From a practical point of view Coke and his associates in opposition to the Crown obviously would not have relied on the courts as the protectors of the constitution. All that was most unconstitutional in Charles' government-ship-money, tonnage and poundage, dispensation of statutes, the punishment of members of Parliament for acts done in Parliament-all these had been declared lawful by the courts-not without strong opposition.

There is, therefore, a difference between the doctrine of judicial review which Coke and the moderate monarchists and Presbyterians supported and that of the Puritans proper. The latter acknowledged no limitation on the power of Parliament except the express prohibition of God. They had no interest in separated and balanced powers of government. They much preferred concentrated power in that branch of the government through which their ideas of Church and State were likely to be fulfilled. The limitation of the divine law was real enough in their minds, but the likelihood of it being violated by a Puritan Parliament-or indeed any English Parliament -was not great.

After 1688, England, while still nominally governed by the "Three Estates" of king, lords and commons, quietly eliminated the king from any effective share and was ruled for a century and a half by a Parliament in which the lords and commons were merely two groups of landed gentry to which were added some of the great merchants. The Puritan theory that only the divine law restricted Parliament was retained and echoes of Coke and St. Germain are not uncommon. But no judge, not even Holt in City of London v. Wood ${ }^{54}$ ventured to go quite so far as Coke did; and in Blackstone the famous declaration is a mere ritual pronouncement.

That is to say, when Parliament became in practice almost omnipotent, the power of the courts over it ceases to be more than an innocuous theoret-

53. I BL. CoMMr. *245.

54. I2 Mod. 609 (170I). 
ical suggestion that there is an acknowledged moral authority which no political agent will wish to disregard. While the royal power was still realit was still real even when Holt decided in City of London v. Wood-limitations on Parliament were found by judges more freely, were actually enforced as to specific statutes, and could be enumerated in principles that almost amount to a written constitution.

The fact that these principles were referred to a written document which does not really contain them, i. e. Magna Charta, is not important. What is noteworthy is that so long as a real judicial review did exist in England, it seems to have served the interests of the royal power rather than that of the ordinary citizen. While it is true that, except for the extreme Levellers, the Puritans made no pretense to be democratic in organization, they approached democratic doctrine far more than their opponents did. With each increase in democracy, there followed an increase in the power of Parliament-especially of the House of Commons-and after the second Reform Bill, the last faint allusions to the doctrine so boldly put into effect by Coke in Bonham's case disappear altogether.

The seventeenth century created modern thought on a great many matters. It did not, however, create modern democracy which was gradually developed out of the revolutionary movements that began in 1776 . Neither the doctrine of the separation of powers nor its somewhat factitious corollary, judicial review of legislation, were part of the democratic impulse. In the seventeenth century, they are set forth as part of the attempt to save the royal prerogative-even if in a form that was less than absolutists like James $I$ and Hobbes and Filmer demanded. The danger to autocracy then lay in a Parliament in which a new social class was an active element. When judicial review and the separation of powers were reasserted in the United States, it was once more as a conscious reaction to the rise in importance of a new social class-in this case a really democratic and almost propertyless class.

The Puritans' share in these doctrines was limited to a religious application and was used only so long as the religious aspect of governmental organization was a living issue. During the Commonwealth, except as warnings against Papacy and Prelacy, these ideas had no importance. The theocracies of Massachusetts and Connecticut made almost no use of them. The one instance cited in our textbooks dealt with a question of church government. Neither a real judicial control nor a real separation of powers would have pleased the Puritans either in England or in New England. They were not democrats but they prepared the way for democracy, and neither of those two famous doctrines can lay much claim to democratic intention or result. 
For Montesquieu, separation of powers was a weapon against autocracy. ${ }^{55}$ There was no existing parliamentary body in France, and the great model of the English Parliament could not have been immediately created and in any case, if the model were followed, would have involved a royal veto. There was, however, an existing theoretical check on autocracy in the parlements, which were courts. Montesquieu himself was president of one of them. If this uncertain and ineffective check could be given reality, an existing body was at hand in France to secure a practical application of the theory of separation and achieve the result intended. ${ }^{56}$ One may hazard the guess that if Montesquieu had foreseen that the theory of the separation of powers and the judicial control of the executive and the legislature could be as effectively used against the interests of a democracy as against those of an autocracy, he would have accepted that as an additional demonstration of the soundness of his general doctrine. ${ }^{57}$ It was not to make a peasant the political equal of the Baron de Secondat that the Spirit of the Laws was written. The Puritans, on the other hand, although they excluded Jews, Pagans, Papists, Prelatists, Anabaptists, Latitudinarians, Arminians, Socinians and many other ists and ians, excluded them for their perversity, not for their fundamental incapacity. If these persons joined the goodly company, the fact that an omnipotent Parliament of their choosing would be rank democracy, would not have shocked even Cromwell. The Elect were all equal.

55. The special influence of the doctrine of Montesquieu on the French Revolution and modern French constitutional law, lies outside of this paper. The fullest discussion is that of I Esmein, Elements de Droit Constitutionei (i8g6) 64I et seq. It soon became apparent that the separation was not meant to imply complete equality nor to impair the supremacy of the legislative power as exercised by a really popular assembly. None the less the notion of separation was fundamental. "The tyrants", said St. Just on April 24, 1793, "divided the people in order to rule over them. Divide power, if you wish liberty to rule." I6 MoNITEUR 25.

56. For the history of the French parlements, cf. 3 VIOLder, HistoIre DEs Institutrons Politiques et Administratives de la France (I903) 308-363. The struggle between the Crown and the parlements during Montesquieu's lifetime is illustrated in Flammermont, Rémontrances du Parlement de Paris aU XVIII ste siele (I888-I898).

57. The reliance on Montesquieu is another illustration of the use of the same authority for the most diverse purposes. His theory was not only cited by St. Just, loc. cit. supra note 55, as a bulwark against autocracy, but he was publicly eulogized by J. P. Marat, in a speech delivered on March 28, 1785 (ed. 1883 by Bregetz). On the other side Burke hailed him as the greatest genius of his age, Io Works 355 , and such indurated enemies of political liberty as Hegel and Treitschke regarded him as their precursor. Cf. Brie, Montesquieu (Germany, 1867) Ig PREUSS. JAHRBUCH 374; Trescher, Montesquieus Einfluss anf die Geschichtsand Staatsphilosophie (Germany, I9I8) 42 ScHMOLlers JaHrbuce 472. 